O. Oliinyk, Dr of Law, Prof.

Taras Shevchenko National University of Kyiv, Kyiv, Ukraine

\title{
WAYS TO RESOLVE AND OVERCOME CONFLICTS IN CRIMINAL LAW OF UKRAINE
}

The purpose of the article is to find the best ways to resolve conflicts in the criminal law of Ukraine. Methods. Methodological tools are selected in accordance with the purpose, specifics of the object and subject of research. The main one is general dialectical method of scientific knowledge of real legal phenomena. Special research methods used in the study are: the method of systematic analysis, formal legal, interpretation of law, comparative law, modeling. The theoretical basis of the study is the latest scientific works in the chosen field of research. Results. As proved during the analysis of the legal literature, there is the following list of effective ways to resolve and prevent conflicts in law, which can be extrapolated to the field of criminal law: 1) unification of law; 2) harmonization of law; 3) approximation of law; 4) clear delineation of powers of public authorities; 5) monitoring of normative legal acts; 6) creation of model laws; 7) interpretation of law; 8) improvement of legislation. Conclusions. As a result of the study, it is proposed to apply different principles to overcome conflicts depending on their type (in particular, "a special law repeals a general law", "a later law cancels an earlier one", "the next general law does not cancel an earlier special law of similar legal force"). Types of "conflict rules" in the sources of criminal law are presented primarily depending on the specific type of such sources. Modern legislation, including criminal, contains virtually no rules aimed at overcoming intersectoral conflicts, but conflicts of law in various areas of Ukrainian law create significant problems in law enforcement.

Keywords: conflict of law; reducing conflicts; unification of law; harmonization of law; interpretation of law; approximation of law.

Bulletin of Taras Shevchenko National University of Kyiv. Legal Studies, 2021; 1 (116): 44-47

УДК: 346.3

DOI: https:doi.org/10.17721/1728-2195/2021/1.116-9
ISSN 1728-2195

(C) Taras Shevchenko National University of Kyiv,

Publishing center "Kyiv University", 2020

А. Погоріленко, асп.

ORCID ID: 0000-0001-7246-526X

Київський національний університет імені Тараса Шевченка, Київ, Україна

\section{ЗАКОНОДАВЧЕ РЕГУЛЮВАННЯ ГОСПОДАРСЬКО-ДОГОВІРНИХ ВІДНОСИН У СФЕРІ ЕЛЕКТРОННОÏ КОМЕРЦІї}

Досліджується Закон України "Про електронну комерцію", профільний нормативно-правовий акт у відповідній сфері, на предмет обсягу його нормативно-правового регулювання, зокрема щодо включення господарськодоговірних відносин до його спектру. Як було виявлено за результатами дослідження, відповідно до міжнародної практики, сфера електронної комерції включає різноманітні види правовідносин, включаючи такі: В2С (БізнесСпоживач), C2C (Споживач-Споживач), B2G (Бізнес-Уряд), G2B (Уряд-Бізнес) і В2B (Бізнес-Бізнес), причому саме відносини типу В2В, тобто господарсько-договірні, є найбільшим її сегментом. Незважаючи на це, як було виявлено за результатами аналізу законодавства, профільний закон України у сфері електронної комерції не враховує потреби практики та виключає цей найбільший сегмент відповідної сфери з обсягу свого правового регулювання. Більше того, аналіз ключових положень відповідного закону, які врегульовують суб'єктний склад учасників відносин у сфері електронної комерції дав можливість зробити висновок, що суб'єкти господарювання, які бажають укласти між собою угоду, взагалі не вважатимуться учасниками відносин у сфері електронної комерції. Як наслідок, до сторін господарського договору, який за всіма ознаками належить до сфери електронної комерції, не застосовуються положення профільного закону про обов'язки продавця (виконавця, постачальника) товарів, робіт, послуг у сфері електронної комерції, обов'язки покупця у сфері електронної комерції, момент підписання електронного правочину. Виключення учасників господарсько-договірних відносин із обсягу правового регулювання Закону України "Про електронну комерцію" в цілому може справити негативний вплив як на розвиток електронної комерції в Україні, так і на розвиток господарсько-договірних відносин у нашій державі.

Ключові слова: суб'єктний склад учасників відносин у сфері електронної комерції; Закон України "Про електронну комерцію"; недосконалість правового регулювання; звуження суб'єктного складу відносин; міжнародна практика електронної комериії.

ВСтУП. Розвиток сфрери електронної комерції щороку набуває все більших масштабів. Згідно з даними, оприлюдненими 29 березня 2019 р. Конференцією ООН по торгівлі та розвитку (ЮНКТАД) у Женеві [1], світові продажі у сфрері електронної комерції у 2017 р. зросли на $13 \%$, досягнувши приблизно 29 трлн дол. Електронна комерція типу Бізнес-Споживач (В2С), була тим сегментом, що найбільше зростав, отримавши показник росту $22 \%$ і досягнувши 3,9 трлн дол у 2017 р.

Та, незважаючи на це, електронна комерція типу Бізнес-до-Бізнесу (В2В) продовжувала домінувати - на неї припадало $88 \%$ усіх онлайн-продажів. 3 огляду на це, найбільший сегмент сфери електронної комерції складають відносини саме господарсько-договірного спектру.

Вищенаведені дані свідчать про те, що господарсько-договірні відносини у сфері електронної комерції потребують належного врегулювання, як на рівні окремої держави, так і на міжнародному рівні, що і визначає актуальність цієї статті.

Закон України "Про електронну комерцію" [2] (далі Закон) є засадничим нормативно-правовим актом у сфе- рі електронної комерції. Він узагальнив і встановив права й обов'язки учасників відносин у сфері електронної комерції, розмежував поняття "електронної комерції" та "електронної торгівлі", встановив порядок вчинення електронних правочинів із застосуванням інформаційнотелекомунікаційних систем. Та, як і будь-який нормативно-правовий акт, що врегульовує відносно нову сферу суспільного буття, він не позбавлений недоліків, про що неодноразово зазначалося в науковій літературі, зокрема в аспекті термінологічних неузгодженостей [3, с. 33], відсутності переліку необхідних реквізитів оригіналу електронного документу $[4$, с. 70$]$ тощо.

Одним із концептуальних недоліків Закону $є$ також виключення $з$ обсягу його правового регулювання відносин у сфері електронної комерції типу В2В, або ж господарсько-договірних відносин у сфері електронної комерції. Світова практика доводить, що електронна комерція $€$ широким поняттям, яке не можна зводити виключно до відносин торгівлі між суб'єктами господарювання й кінцевими споживачами (відносини типу "бізнес-споживач", або ж "В2С"). Тим не менше, як буде 
продемонстровано нижче, саме це фрактично і відбувається в Законі й негативно може впливати на розвиток електронної комерції в Україні.

Об'єктом цього дослідження є Закон України "Про електронну комерцію". Метою цього дослідження $€$ вивчення обсягу правового регулювання Закону в аспекті включення в нього господарсько-договірних відносин у ссрері електронної комерції. Пропонується дослідити чи Закон врегульовує лише комерційні відносини між суб'єктом господарювання і кінцевим споживачем, чи так само врегульовує договірні відносини між двома суб'єктами господарювання у сфері електронної комерції. За результатами дослідження вноситимуться пропозиції щодо вдосконалення чинного законодавства у сфері електронної комерції.

Стан вивчення проблематики. Теоретичні підвалини права, які стали основою для дослідження проблематики цієї роботи, розроблялися в роботах О. Скакун [5]. Теоретичне підґрунтя господарського права розробляв В. Щербина [6], сформувавши фундамент для аналізу господарсько-договірних відносин у сфрері електронної комерції. Теоретичні ж основи електронної комерції як такої досліджувалися, зокрема, у працях В. Рєзнікової [7], А. Чучковської [8] та О. Шалеви [9]. Проте в наукових роботах практично не звертається увага на проблему виключення 3 обсягу правового регулювання Закону правовідносин у сорері електронної комерції типу B2B (бізнес-бізнес), B2G (бізнес-уряд), G2B (урядбізнес) та ін. Незважаючи на те, що існування такої проблеми підкреслювали деякі вчені, зокрема В. Плескач, Т. Затонацька, Л. Олексюк [10, с. 80] і В. Чайковська [11, с. 43], більш детального дослідження потребує саме господарсько-договірний аспект відповідної проблематики, з огляду на об'єм сегменту господарсько-договірних відносин у сфері електронної комерції.

ОСНОВНІ РЕЗУЛЬТАТИ. ВідПовідність профільного закону міжнародній комерційній практиці. Станом натепер, електронна комерція у світовому економічному співтоваристві набуває різноманітних форм. Вичерпну класифікацію фрорм електронної комерції навела у своїй роботі І. В. Ховрак [12, с. 18]. Нею були виокремлені такі форми електронної комерції В2B (business - to business), $\mathrm{B} 2 \mathrm{C}$ (business - to - consumer), $\mathrm{C} 2 \mathrm{C}$, (consumer - to - consumer), B2G (business - to government), G2B (government - to - business).

Попри зазначене різноманіття форм електронної комерції, Закон у нинішній редакції по суті виключає найбільший сегмент електронної комерції, а саме господарсько-договірні відносини (В2В). Вказане можна прослідкувати, ретельно проаналізувавши Розділ II Закону. Він, власне, встановлює три види учасників відносин у сорері електронної комерції, а саме (I) суб'єкти електронної комерції, (II) постачальники послуг проміжного характеру в інформаційній сфері, (III) органи державної влади й органи місцевого самоврядування в частині виконання ними функцій держави або місцевого самоврядування. Пунктом 15 ч. 1 ст. 3 визначається, що суб'єкт електронної комерції - суб'єкт господарювання будь-якої організаційно-правової фоорми, що реалізує товари, виконує роботи, надає послуги з використанням інфрормаційно-телекомунікаційних систем, або особа, яка придбаває, замовляє, використовує зазначені товари, роботи, послуги шляхом вчинення електронного правочину. У свою чергу, виходячи зі змісту Розділу II Закону, можна зробити висновок, що суб'єкти електронної комерції можуть мати статус продавця (виконавця, постачальника), або ж покупця (замовника, споживача) товарів, робіт, послуг в електронній комерції. Виходячи з визначення поняття "суб'єкт електронної комерції", робимо висновок, що до продавця (виконавця, постачальника) належить суб'єкт господарювання будь-якої організаційно-правової форми що реалізує товари, виконує роботи, надає послуги з використанням інформаційно-телекомунікаційних систем. 3 іншого боку, суб'єктний склад покупця (замовника, споживача) викликає багато запитань.

Проблематика суб'єктного складу покупця (замовника, споживача) товарів, робіт, послуг в електронній комерції (далі - "покупець у сорері електронної комерції") пов'язана з тим, що зазначене вище визначення терміну "суб'єкт електронної комерції" співвідносить поняття покупця у сфері електронної комерції з поняттям "особи", що саме по собі не дає зрозуміти, мається на увазі фізична чи юридична особа, або ж обидві одночасно. 3 іншого боку, положення Закону уникають конкретизації поняття "особи". Отже, виникає певна невизначеність.

Ідучи від зворотного, можна було б зазначити, що поняття "особи" саме по собі включає в себе як юридичну так і фрізичну особу, а також послатися на визначення покупця у ряді нормативно-правових актів України $[13,14]$, що включають в себе як юридичну, так і фізичну особу. Ця лінія аргументації могла би завершити дискусію на користь Закону, якби не посилання у його тексті, а саме в абзаці 2 ч. 1 ст. 8 Закону на Закон України "Про захист прав споживачів" [15]. Так, цим абзацом встановлюється, що Покупець (замовник, споживач) товарів, робіт, послуг у сорері електронної комерції за обсягом своїх прав та обов'язків прирівнюється до споживача в разі укладення договору поза торговельними або офрісними приміщеннями та в разі укладення договору на відстані відповідно до Закону України "Про захист прав споживачів".

У свою чергу, у згаданому останнім законі споживач визначається як фізична особа, яка придбаває, замовляє, використовує або має намір придбати чи замовити продукцію для особистих потреб, безпосередньо не пов'язаних із підприємницькою діяльністю або виконанням обов'язків найманого працівника. Незважаючи на те, що в абзаці 2 ч. 1 ст. 8 Закону прямо не йдеться не про зрівняння статусу покупця у сфері електронної комерції в Законі зі статусом споживача у Законі "Про захист прав споживачів", а радше про надання їм однакового обсягу прав та обов'язків, безпосереднє звернення до переліку відповідних прав та обов'язків пояснює те, що малося на увазі. Так, серед прав споживача у ст. 4 Закону України "Про захист прав споживачів" згадуються права, які можуть належати лише фрізичній особі, зокрема право на відшкодування моральної шкоди та на об'єднання в громадські організації споживачів. Стаття 5 відповідного закону також вказує, що держава надає можливість споживачам здобувати знання і кваліфікацію, необхідні для прийняття самостійних рішень під час придбання та використання продукції відповідно до потреб. Очевидно, юридична особа не може здобувати знання та кваліфікацію. Щодо обов'язків, також викликає великий сумнів можливість юридичної особи "уважно ознайомитися" із правилами експлуатації, викладеними в наданій виробником (продавцем, виконавцем) документації, яка вказано у ч. 3 ст. 4 відповідного закону. 
Отже, можемо зробити висновок, що Законом обмежується статус покупця у ссрері електронної комерції виключно до фрізичної особи, що не відповідає міжнародній практиці, де до електронної комерції належать будь-які онлайн-зобов'язання щодо продажу, що призводять до імпорту чи експорту товарів і послуг [16, с. 2].

3 огляду на вищенаведене, можна зробити висновок, що станом натепер господарсько-договірні відносини не врегульовані Законом. Тобто укладення, виконання та реалізація господарських договорів у сфері електронної комерції не входить до обсягу регулювання Закону. Більше того, із фрормулювань, передбачених у Законі, можна зробити висновок про те, що суб'єкти господарювання, які бажають вчинити між собою електронний правочин, взагалі не можуть вважатися учасниками відносин у сфері електронної комерції. Так, ч. 1 ст. 6 Закону перебачено, що учасниками відносин у сорері електронної комерції є суб'єкти електронної комериії, постачальники послуг проміжного характеру в інфрормаційній сфрері, органи державної влади та органи місцевого самоврядування в частині виконання ними фуннкцій держави або місцевого самоврядування. Враховуючи визначення терміна "суб'єкт електронної комерції", наявне в Законі, про що зазначалося вище, і доведене вище обмеження статусу покупця у сфері електронної комерції виключно до фрізичної особи, складається правова ситуація, коли суб'єкти господарювання, що реалізують укладають, виконують і розривають електронні договори, взагалі не вважаються учасниками відносин у сфері електронної комерції відповідно до Закону, хоча, де-фракто, ними є.

Наслідки виключення В2В-сегменту 3 обсягу регулювання. Як наслідок, суб'єкти господарювання, не маючи статусу учасника відносин у сфері електронної комерції за Законом, позбавляються правового регулювання, ним передбаченого для відповідних учасників. Унаслідок цього, до господарсько-договірних відносин не застосовуються положення Закону про обов'язки продавця (виконавця, постачальника) товарів, робіт, послуг у сорері електронної комерції (ч. 1-3 ст. 7 Закону), обов'язки покупця у сфрері електронної комерції (ч. 2,3,5 ст. 8 Закону), момент підписання електронного правочину (ст. 12) тощо. Отже, суб'єкти господарювання у відповідній сфері позбавляються всіх переваг, передбачених для учасників відносин у сфрері електронної комерції за Законом. Під час подальшого вдосконалення нормативно-правової бази, що регулює відносини у сфері електронної комерції, виявлена проблема може мати негативний вплив на статус суб'єктів господарювання у сфері електронної комерції, зокрема на обсяг їхніх правових можливостей, рівність прав та обов'язків з іншими учасниками правовідносин у сфері електронної комерції.

Вказані недоліки Закону потребують корекції. Рекомендується більш детально прописати Закон в контексті суб'єктного складу учасників відносин у сфері електронної комерції. Пропонованою законодавчою ініціативою $€$ внесення до ст. 8 Закону положення про те, що покупцем у сфері електронної комерції $€$ фрізичні та юридичні особи, зокрема суб'єкти господарювання.

ВИСНОВКИ. За результатами цього дослідження було виявлено, що з обсягу правового регулювання Закону виключений найбільший сегмент електронної комерції - господарсько-договірні відносини між суб'єктами господарювання (В2В). Було виявлено, що положення абзацу 2 ч. 1 ст. 8 Закону України "Про елект- ронну комерцію" прирівнюють обсяг прав та обов'язків покупця (замовника, споживача) товарів, робіт, послуг у сфрері електронної комерції до споживача в разі укладення договору поза торговельними або офісними приміщеннями та в разі укладення договору на відстані відповідно до Закону України "Про захист прав споживачів". Ураховуючи те, що відповідно до останнього закону споживач може бути виключно фрізичною особою, зроблено висновок про те, що суб'єкт господарювання не може бути покупцем (замовником, споживачем) товарів, робіт, послуг у ссрері електронної комерції. Було також виявлено, що внаслідок вказаного підходу до визначення статусу покупця (замовника, споживача) товарів, робіт, послуг у сфері електронної комерції складається правова ситуація, коли суб'єкти господарювання під час укладання, розірвання та виконання електронних правочинів взагалі не вважаються учасниками відносин у сфері електронної комерції відповідно до Закону України "Про електронну комерцію". Як наслідок, до господарсько-договірних відносин у сорері електронної комерції не застосовуються положення Закону України "Про електронну комерцію" щодо обов'язків продавця (виконавця, постачальника) товарів, робіт, послуг в електронній комерції (ч. 1-3 ст. 7 Закону), обов'язків покупця у сфрері електронної комерції (ч. 2,3,5 ст. 8 Закону), моменту підписання електронного правочину (ст. 12) тощо. Отже вони, на відміну від визнаних учасників відносин у сорері електронної комерції, позбавляються всіх переваг правової врегульованості та правової визначеності.

За результатами цього дослідження було запропоновано внести зміни до ст. 8 Закону стосовно того, що покупцем у сорері електронної комерції $\epsilon$ фрізичні та юридичні особи, зокрема суб'єкти господарювання.

\section{Список використаної літератури}

1. UNCTAD. Global e-commerce sales surged to $\$ 29$ trillion. 2019. URL : https://unctad.org/en/pages/newsdetails.aspx?OriginalVersionID=2034 (дата звернення 23.08.2020 року)

2. Про електронну комерцію: Закон України № 675-VIII від 03.09.2015 р. в редакції від 19.04.2020 р. // Відомості Верховної Ради (ВВР). - 2015. - № 45. - ст. 410 [Електронний ресурс]. - Режим доступу: https://zakon.rada.gov.ua/laws/show/675-19\#Text (дата звернення: 23.08.2020 року)

3. Зубатенко О. Аналіз поняття "Електронна комерція" у контексті закону України "Про електронну комерцію" / О. Зубатенко // Актуальні проблеми вітчизняної юриспруденції. - 2016. - № 1. - С. 32-34 [Електронний ресурс]. - Режим доступу: http://www.irbis-nbuv.gov.ua/cgibin/irbis nbuv/cgiirbis 64 exe?|21DBN=LINK\&P21DBN=UJRN\&Z21ID= $\& S 21 \mathrm{REF}=10 \& S 21 \mathrm{CNR}=20 \& S 21 \mathrm{STN}=1 \& S 21 \mathrm{FMT}=\mathrm{ASP}$ meta\&C21COM $=S \& 2 \_S 21 P 03=F I L A=\& 2 \_S 21 S T R=a p v u \_2016 \_1 \_9$ (дата звернення 23.08.2020 року).

4. Кучаковська Н. Правове регулювання укладення електронних господарських договорів / Н. Кучаковська // Зовнішня торгівля: економіка, фрінанси, право. - 2016. - №6. - С. 62-74 [Електронний ресурс]. Режим доступу : http://www.irbis-nbuv.gov.ua/cgi-bin/irbis nbuv/cgiirbis 64.exe? I21DBN=LINK\&P21DBN=UJRN\&Z21ID $=\& S 21 R E F=10 \& S 21 C N R=20 \& S 21 S$ $\mathrm{TN}=1 \& S 21 \mathrm{FMT}=\mathrm{ASP}$ meta\&C21COM=S\&2_S21P03=FILA=\&2_S21STR= uazt 2016_6 9 (дата звернення 23.08.2020 року).

5. Скакун О. Теорія держави і права : підручник / О. Скакун. - Х. : Консум, 2004.

6. Щербина В. Господарське право : підручник / В. Щербина. - К. : Юрінком Інтер, 2013.

7. Рєзнікова В.В. Поняття, значення та перспективи правового забезпечення електронної комерції в Україні / В. В. Рєзнікова // Теорія і практика інтелектуальної власності. - 2015. - № 2. - С. 58-72. [Електронний ресурс]. - Режим доступу: http://www.ndiiv.org.ua/Files2/ 2015_2/10.pdf (дата звернення 23.08.2020 року).

8. Чучковська А. Правове регулювання господарських договорів, що вчиняються через мережі електрозв'язку : дис. ...канд. юрид. наук / А. Чучковська. - К., 2004

9. Шалева О. Електронна комерція: навчальний посібник. Київ: Центр учбової літератури, 2011. 
10. Плескач В. Проблеми розвитку електронної комерції в Україні / В. Плескач, Т. Затонацька, Л. Олексюк // Економіка України. - 2017 № 11. - С. 73-84 [Електронний ресурс]. - Режим доступу : http://nbuv.gov.ua/ UJRN/EkUk_2017_11_6. (дата звернення 23.08.2020 року).

11. Чайковська В. Електронна комерція в україні: сучасний стан та тенденції розвитку / В. Чайковська // Інтелект XXI. - 2016. - № 3. - С. 38 48 [Електронний ресурс]. - Режим доступу : http://www.irbis-nbuv.gov.ua/ cgi-bin/irbis nbuv/cgiirbis 64.exe?C21COM=2\&I21DBN=UJRN\&P21DBN= UJRN\&IMAGE FILE DOWNLOAD=1\&Image file name=PDF/int XXI 2016_3_6.pdf (дата звернення 23.08.2020 року).

12. Ховрак І. Електронна комерція в Україні: переваги та недоліки / / І. Ховрак // Економіка, Фінанси, Право. - 2013. - № 4. - С. 16-20 [Електронний ресурс]. - Режим доступу: http://www.irbis-nbuv.gov.ua/ cgi-bin/irbis_nbuv/cgiirbis_64.exe?C21COM=2\&I21DBN=UJRN\&P21DBN= UJRN\&IMAGE FILE DOWNLOAD=1\&Image file name=PDF/ecfipr 2013 4_7.pdf (дата звернення 23.08.2020 року).

13. Про захист прав покупців сільськогосподарських машин: Закон України від 05.06.2003 р. № 900-IV в редакції від 11.02.2015 р. // Відомості Верховної Ради України (ВВР). - 2003. - № 38. - ст. 315. [Електронний ресурс]. - Режим доступу: https://zakon.rada.gov.ua/laws/ show/900-15\#Text (дата звернення 23.08.2020 року).

14. Порядок відчуження об'єктів державної власності: затверджений Постановою Кабінету Міністрів України від 6 червня 2007 р. № 803 (в редакції Постанови Кабінету Міністрів України від 23 жовтня 2019 р. № 884) [Електронний ресурс]. - Режим доступу : https://zakon.rada.gov.ua/ laws/show/803-2007-\%D0\%BF\#Text (дата звернення 23.08.2020 року).

15. Про захист прав споживачів: Закон України від 12.05.1991 р. № 1023-XII // Відомості Верховної Ради УРСР (ВВР). - 1991. - № 30. ст. 379. [Електронний ресурс]. - Режим доступу : https://zakon.rada.gov.ua/ laws/show/1023-12\#Text (дата звернення 23.08.2020 року).

16. United States General Accounting Office Report to the Ranking Senate Minority Member of the Joint Economic Committee: International electronic commerce. Definitions and Policy Implications. 2002 [Електронний ресурс]. - Режим доступу : https://www.gao.gov/new.items/d02404.pdf (дата звернення 23.08.2020 року).

\section{References}

1. UNCTAD. Global e-commerce sales surged to $\$ 29$ trillion. (2019). https://unctad.org/en/pages/newsdetails.aspx?OriginalVersionID=2034

2. Pro elektronnu komerciju, Zakon Ukrai'ny [On e-commerce, Law of Ukraine] №675-VIII (2020). https://zakon.rada.gov.ua/laws/show/67519\#Text (in Ukrainian)

3. Zubatenko, O. (2016). Analiz poniattia "Elektronna komertsiia" u konteksti zakonu Ukrainy "Pro elektronnu komertsiiu" [Analysis of the concept of "E-commerce" in the context of the law of Ukraine "On e-commerce"]. Aktualni problemy vitchyznianoi yurysprudentsii, [Actual problems of domestic jurisprudence], (1), 32-34 (in Ukrainian).

4. Kuchakovska, N. (2016). Pravove rehuliuvannia ukladennia elektronnykh hospodarskykh dohovoriv (Legal regulation for concluding

A. Pohorilenko, PhD Student

Taras Shevchenko National University of Kyiv, Kyiv, Ukraine electronic business agreements). Zovnishnia torhivlia: ekonomika, finansy, parvo [Foreign trade: economics, finance, law], (6), 62-74.

5. Skakun, O. (2004). Teoriia derzhavy $i$ prava [Theory of State and Law]. Konsum (in Ukrainian).

6. Shcherbyna, V. (2013). Hospodarske pravo [Commercial Law]. Yurinkom Inter (in Ukrainian).

7. Rieznikova, V. (2015). Poniattia, znachennia ta perspektyvy pravovoho zabezpechennia elektronnoi komertsii v Ukraini [The concept, meaning and prospects of legal support of e-commerce in Ukraine]. Teoriia praktyka intelektualnoi vlasnosti [Theory and practice of intellectual property], (2), 58-72 (in Ukrainian).

8. Chuchkovska, A. (2004). Pravove rehuliuvannia hospodarskykh dohovoriv, shcho vchyniaiutsia cherez merezhi elektrozviazku [Candidate dissertation], Taras Shevchenko national university of Kyiv (in Ukrainian).

9. Shaleva, O. (2011). Elektronna komertsiia (E-commerce). Tsentr uchbovoi literatury (in Ukrainian)

10. Pleskach, V., Zatonatska, T., \& Oleksiuk, L. (2017). Problemy rozvytku elektronnoi komertsii $\vee$ Ukraini [Problems of e-commerce development in Ukraine]. Ekonomika Ukrainy [Economy of Ukraine], (11), 3-84 (in Ukrainian)

11. Chay̆kovska, V. (2016). Elektronna komertsiia v ukraïni: suchasnyy̆ stan ta tendentsiï rozvytku [E-commerce in Ukraine: current state and development trends]. Intelekt XXI, (3), 38-48 (in Ukrainian).

12. Khovrak, I. (2013) Elektronna komertsiia v Ukraini: perevahy ta nedoliky [E-commerce in Ukraine: advantages and disadvantages]. Ekonomika, Finansy, Pravo [Economics, Finance, Law], (4), 16-20 (in Ukrainian).

13. Pro zakhyst prav pokuptsiv silskohospodarskykh mashyn, Zakon Ukrai'ny [On protection of the rights of buyers of agricultural machinery, Law of Ukraine] № 900-IV (2015). https://zakon.rada.gov.ua/laws/show/900$15 \#$ Text (in Ukrainian).

14. Poriadok vidchuzhennia obiektiv derzhavnoi vlasnosti, Resolution of the Cabinet of Ministers of Ukraine [Procedure for alienation of state property, Resolution of the Cabinet of Ministers of Ukraine] №884 (2019). https://zakon.rada.gov.ua/laws/show/803-2007-\%D0\%BF\#Text (in Ukrainian).

15. Pro zakhyst prav spozhyvachiv, Zakon Ukrai'ny [On consumer protection, Law of Ukraine] №1023-XII (1991). https://zakon.rada.gov.ua/laws/ show/1023-12\#Text (in Ukrainian)

16. United States General Accounting Office Report to the Ranking Senate Minority Member of the Joint Economic Committee: International electronic commerce. Definitions and Policy Implications. (2002). https://www.gao.gov/new.items/d02404.pd

Received: $09 / 09 / 2020$

1st revision: $28 / 10 / 2020$

Accepted: $15 / 12 / 2020$

\section{LEGAL REGULATION FOR CONTRACTUAL RELATIONS IN THE FIELD OF ELECTRONIC COMMERCE}

This paper examines the Law of Ukraine "On e-commerce", central legal act in the relevant field, in terms of the scope of its legal regulation, in particular on the inclusion of B2B contractual relations in its range. According to the research, in accordance with international practice, the field of e-commerce includes various types of legal relations, including the following: B2C (Business-Consumer), C2C (Consumer-Consumer), B2G (Business-Government), G2B (Government-Business) and B2B (Business-Business). At the same time, B2B relations makes up its largest segment. Nevertheless, as revealed by the analysis of the legislation, abovementioned law of Ukraine in the field of e-commerce does not take into account the needs of economy and excludes this largest segment of e-commerce from the scope of legal regulation. Moreover, analysis of the key provisions of the relevant law governing the composition of participants of e-commerce has led to the conclusion that business entities wishing to enter into an agreement in the relevant field will not be considered as e-commerce subjects at all. As a result, they are deprived of the entire scope of legal regulation provided by this law for "selected" participants of e-commerce, i.e. the provisions of the relevant law on the obligations of the seller (performer, supplier) of goods, works, services in the field of e-commerce, the obligations of the buyer in the field of e-commerce, provisions on the moment of signing of the electronic agreement etc. Hence, these provisions do not apply to the parties of the business agreement, which by all indications belongs to the field of e-commerce. All the above mentioned may have a negative impact on the development of e-commerce and B2B relations in Ukraine. According to the results of the study, it was concluded that the Law of Ukraine "On e-commerce" should be supplemented by provisions including $B 2 B$ relations to the field of e-commerce.

Keywords: the Law of Ukraine "On e-commerce"; imperfection of legal regulation; development of e-commerce; international practice; B2B relationship. 